\title{
Conferences/Seminars
}

\section{Family and Law in Islam}

\section{Istanbul, Turkey}

Shawwäl/16-18, 1409/May 17-21, 1989

Without fanfare, a significant conference on "Family and Law in Islam", took place at the Ramada Inn, Istanbul, May 17-21 1989. More than twentyfive invitees from Britain, Egypt, Hungary, India, Pakistan, the United States, and Grand Muftis of Syria and North Yemen attended the conference. Also attending were the essential support personnel of the Council of World Religions (CWR), and its Executive Director, Frank Kaufmann. The CWR, a subsidiary of the International Religious Foundation (IRF) did everything possible to make the conference a very rewarding experience for all participants.

Unlike other conferences, only major assumptions and conclusions were presented by the authors to set the stage for discussion. To facilitate the discussions, the organizers had distributed papers a month ahead of time. A certain "pairing" was also attempted, but this was by no means exclusive, and a major part of the proceedings consisted of free-range discussions, punctuated by the Grand Mufti of Syria and his stories on topics ranging from camels to watermelons, reflecting on interconnections, between and relative importance of particular situations.

Since the CWR plans to publish, in full or in part, contributions to this conference, and since these tend to be well documented and meaty, we will only provide here an idea of the flavor and scope of the topics and discussions. Mohsin Labban of Alexandria, Egypt was the first to discuss the spiritual and moral aspects of the Shariah concluding that a woman's fulfilment is in her inclination to possess. By learning to coexist with her husband's other wife or wives, she may overcome egotism, selfishness, and jealosy. Abdallah Nuruddin Durkee of the Darul Islam Foundation, defined secularity and secularism and showed that none of these institutions provide answers to problems facing a family. Then Imtiaz Ahmad of Karachi University presented his paper on the role of family in Islamic society, upholding traditional Islamic values and denouncing Western intrusions. Other participants from Pakistan were as varied as their assumptions. Abdul Rashid of Karachi University described the status of women in Islam, stating that there is nothing in Islam to bar a woman from being the head of the government, as is the case in contemporary Pakistan. Hassan Qasim Murad, also of Karachi University, discussed the question of equality and equal rights, contending that inequality of sexes, inferiority of woman to man, was written in the sacred texts, the 
Quran and Hadith, and it was accepted and accentuated by a variety of faithful and enthusiastic medieval Muslim intellectuals. Hence, women are inferior to men and the present debate of equal rights is unnecessary and illogical. Such an assertion was bound to evoke controversy and criticism, and so it did. Mumtaz Ahmad challenged Qasim Murad on three grounds: sources, methodology and substantive arguments. Ahmad described Murad's sources or spurious, his methodology as "convoluted" and his arguments as polemical.

Three presentations from India dealt with various aspects of Muslim family law in secular India. Upholding Shariah as the basis of Muslim family law, Mushirul Haq of Kashmir University pointed out that major difficulties arise when various schools of Muslim jurisprudence do not agree on one interpretation of the Shariah. Dr. Ali Ashraf of Jamia Millia discussed the status of women and Islamic law, and Mohammad Shafi of Aligarh Muslim University presented a paper on Women, Islam, and Family in India. Both of these papers discussed the Shah Bano case as an infringment on Muslim rights and provided their interpretations of the present situation in India.

Abdel Rahman Balaza Milhalffy and Mohammad Manazir Ahsan discussed the role and responsibilities of a Muslim family in Western society. Abdel Rahman focused on the situation in Hungary and Manazir Ahsan described the problems faced by Muslims in Britain. Noura Durkee of Madrasat Khalid al-Islam was unique in being the only woman participant in the conference. Her presentation, "Marriage for a Muslimah: Surrender to him for Him," was interesting in many respects.

The concluding session was for suggestions and impressions. The overriding impression of the participants was that of genuine achievement. However, there was a recognized need for further, deeper contacts between peoples and a common concern for greater harmony and mutual respect among the believers of the same and different religions. This highly successful meeting in Istanbul can be viewed as an important milestone in the current debate on the Muslim family.

Mushtaqur Rahman Iowa State University 